\title{
"This uncomatable Book": New Evidence of the Circulation and Reception of the Poetry of James VI/I
}

This article examines manuscript additions in a copy of the first printed work by James VI/I, The Essayes of a Prentise, in the Divine Art of Poesie (1584), held in Winchester College Fellows' Library. This copy, which has not previously been studied, contains a manuscript supplement of three poems by James which were not printed during his lifetime, as well as a unique sonnet in praise of the king and a small set of marks of reading. The article reassesses the picture that has emerged of the circulation of James's poetry in manuscript in light of the evidence provided by the Winchester copy of the Essayes. It also sheds light on the response to the Essayes among Scottish readers through an examination of the panegyric sonnet and marks of reading. 


\title{
"This uncomatable Book": New Evidence of the Circulation and Reception of the Poetry of James VI/I
}

\author{
Carly Watson
}

In 1767 Winchester College received a donation of three thousand books from Alexander Thistlethwayte, a local landowner and former MP whose nephew was beginning his education at the school. ${ }^{1}$ This was the largest donation that the College Library had received since its foundation at the beginning of the fifteenth century, and it had a distinctly literary character: the vast majority of the books given by Thistlethwayte were editions of poetry and drama in classical and modern languages. ${ }^{2}$ Among the books that arrived at the College in 1767 was a copy of The Essayes of a Prentise, in the Divine Art of Poesie (1584), the first printed work by James VI/I. This copy is the first item in a Sammelband containing an assortment of sixteenth- and seventeenth-century publications in quarto, most of them

The first phase of my research for this article was generously supported by Winchester College and the Arts and Humanities Research Council. I wish to thank Geoffrey Day, former Fellows' Librarian of Winchester College, for his invaluable help and guidance, and Richard Foster, the current Fellows' Librarian, for his kind assistance. I am grateful to the journal's anonymous readers for their insightful comments on this essay.

${ }^{1}$ For further biographical information, see A. N. Newman, "Thistlethwayte, Alexander (?1718-71), of Southwick Park, Hants.," in The History of Parliament: The House of Commons, 1754-1790, ed. Sir Lewis Namier and John Brooke, 3 vols. (London, 1964), 3:521. Thistlethwayte's nephew and heir Robert followed his uncle into politics, serving as MP for Hampshire from 1780 to 1790. See John Brooke, "Thistlethwayte, Robert (17551802), of Southwick Park, Hants.," in House of Commons, 1754-1790, ed. Namier and Brooke, 3:521. The College Benefactors' Book records that Thistlethwayte "Sent from his own Library three thousand volumes of Poetry in most of the living and dead languages". Charles Blackstone, "Benefactors ... together with an account of their respective Benefactions," 1784, fol. 117r, Winchester College Muniments 23459.

${ }^{2}$ On the history of the library in the eighteenth century and before, see Walter Oakeshott, "Winchester College Library Before 1750," The Library, 5th ser., 9 (1954): 1-16, and J. M. G. Blakiston, "Winchester College Library in the Eighteenth and Early Nineteenth Centuries," The Library, 5th ser., 17 (1962): 23-45. 
including verse; Thistlethwayte seems to have had this volume bound up himself. ${ }^{3}$ As well as placing his copy of Essayes of a Prentise at the front of the volume, Thistlethwayte drew attention to its bibliographical and historical importance by writing a note on a flyleaf preceding the title page:

This uncomatable [unobtainable] Book has for its author no less a Person than James $1^{\text {st }}$. King of England and it bears Date when he was but 18 years old, \& before his mother was beheaded[.]

Thistlethwayte emphasized the rarity of James's Essayes and correctly noted that the king was still a teenager when it was published. Yet he did not comment on the unique features of the copy in his hands. This copy of Essayes of a Prentise has a remarkable set of manuscript additions. Firstly, three poems by James were copied onto four endpapers; these poems, which are known from other manuscripts, were not printed during James's lifetime. Secondly, a sonnet in praise of the king was inscribed on the first blank page following the opening sequence of commendatory poems. Thirdly and finally, a reader took a pen to two passages in James's translation of 'L'Vranie', a defence of divine poetry by the French Protestant poet Guillaume de Saluste Du Bartas. These additions form an important body of

\footnotetext{
${ }^{3}$ The Sammelband is half bound in leather with marbled paper covering the boards. Many volumes from Thistlethwayte's library have similar bindings. The Sammelband contains the following editions: James VI/I, The Essayes Of A Prentise, In The Divine Art Of Poesie (Edinburgh, 1584), STC 14373; Francis Turner and others, Affectuum Decidua, Or Dve Expressions In honour of the truly noble Charles Capell Esq. (Oxford, 1656), Wing T3273; Thomas Barlow and others, Pietas In Patrem, Or A Few Teares Vpon The Lamented Death Of His Most Deare, And Loving Father Richard Barlow (Oxford, 1637), STC 1441a; A Tragi-Comedy, Called New-Market-Fayre, Or A Parliament Out-Cry, 2nd edn (London, 1649), Wing T2018A; Edward Chamberlayne, Englands Wants: Or Several Proposals Probably beneficial for England (London, 1667), Wing C1839; John Leland, Assertio inclytissimi Arturij Regis Britanniae (London, 1544), STC 15440; De obitu doctissimi et sanctissimi theologi doctoris Martini Buceri (London, 1551), STC 5108; Andrea Navagero, Orationes duae (Paris: Jean Petit, 1531). The volume is catalogued as Book No. 5446 in Winchester College Fellows' Library. On Thistlethwayte's Sammelbände and the culture of compiling in the eighteenth century, see Carly Watson, Miscellanies, Poetry, and Authorship, 1680-1800 (Cham, 2021), 201-11.
} 
evidence concerning the circulation of James's verse in manuscript and the reception of his first venture into print.

Yet the Winchester copy of Essayes of a Prentise has not previously been studied. Until recently, there was no record of its existence in any online library catalogue. ${ }^{4}$ As a result, it is absent from two important surveys of the dissemination of James's poetry in print and manuscript: Sebastiaan Verweij's analysis of surviving copies of the Essayes and Steven May's study of manuscript copies of James's poems outside of the king's own collections. ${ }^{5}$ This essay seeks to establish a more complete picture of the circulation and reception of James's poetry by offering an analysis of the manuscript additions to the Winchester copy of Essayes of a Prentise. The provenance of this copy cannot be traced beyond Thistlethwayte: an inscription on the title page has been erased, and there are no further clues to the identities of earlier owners. The scribes who added the poems and other inscriptions to the Winchester Essayes have also not yet been identified. However, the evidence of the manuscript texts themselves indicates that not long after its publication this copy of the Essayes was in the hands of a Scot who belonged to or had connections with the Jacobean court.

This essay will address the manuscript additions to the Winchester Essayes in the order outlined above. The first section will reconsider the circulation of James's unprinted verse in manuscript in light of the three poems by the king inscribed at the back of this copy. These poems form part of a growing body of evidence that James's use of the printing press

\footnotetext{
${ }^{4}$ In the spring and summer of 2017 records of the library's pre-1700 holdings in the online English Short Title Catalogue (ESTC; http://estc.bl.uk) were significantly expanded. In the process, Winchester College Fellows' Library was added to the list of institutions holding copies of the 1584 Essayes of a Prentise in the ESTC record for the edition (No. S109108). Records of the library's entire collection were made available online via Copac, now Library Hub Discover (https://discover.libraryhub.jisc.ac.uk), in March 2019.

${ }^{5}$ Sebastiaan Verweij, “'Booke, go thy wayes': The Publication, Reading, and Reception of James VI/I's Early Poetic Works," Huntington Library Quarterly 77 (2014): 111-31. Steven W. May, "The Circulation in Manuscript of Poems by King James VI and I," in Renaissance Historicisms: Essays in Honor of Arthur F. Kinney, ed. James M. Dutcher and Anne Lake Prescott (Newark, Del., 2008), 206-24.
} 
to disseminate his verse did not preclude the circulation of some of his poems in manuscript during the same period. The second section will consider the manuscript sonnet copied into the book as an addition to the sequence of commendatory poems contributed by courtiers and public figures. The Winchester Essayes is not the only copy of James's collection that is known to contain additional panegyric poems in manuscript: Verweij has examined a copy in Lambeth Palace Library that includes three manuscript poems lauding James and his book. ${ }^{6}$ But while the poems in the Lambeth Palace Library copy add to a picture of cross-border exchange between James and his English readers, the sonnet in the Winchester copy enhances our understanding of the response to James's poetic self-fashioning in Scottish literary circles. Finally, the third section will examine the reader's marks on the printed text of James's Scots version of 'L'Vranie'. Though they are not extensive, these markings seem to show that one reader of the Winchester Essayes looked for thematic links between the manuscript sonnet and James's own verse and in the process uncovered an error in his translation.

In the 1580s James emerged as a mature and confident king after a long and sometimes turbulent minority. In 1584, the year he turned eighteen, he faced down an English-backed coalition of rebel lords, and his government passed a series of acts consolidating his power over Kirk and state. ${ }^{7}$ Five years later James travelled to Denmark to celebrate his marriage to Anne. The 1580 s and early 1590 s were also James's most productive years as a poet. His first collection of poetry and poetic theory, Essayes of a Prentise, was published in 1584, and it

\footnotetext{
${ }^{6}$ Verweij, “"Booke, go thy wayes"," 121-30. The copy in Lambeth Palace Library, London, is shelfmarked [ZZ]1584.19.

${ }^{7}$ On the events of 1584 and the emergence of "a newly assertive King James," see Alan Stewart, The Cradle King: A Life of James VI and I (London, 2003), 74.
} 
was followed by a second collection, His Maiesties Poeticall Exercises at Vacant Houres, in 1591. ${ }^{8}$ James's output in manuscript was even more extensive. Two of the three extant collections of James's verse in his own hand or in authorized copies have been dated to the 1580s. The first of these, Bodleian Library MS Bodley 165, contains holograph drafts of thirteen poems, four of which appeared in James's printed collections. ${ }^{9}$ According to Sebastiaan Verweij, these "very first royal holographs" were "largely written in the 1580 s". ${ }^{10}$ The second collection, British Library MS Royal 18.B.xvi, contains verse paraphrases of thirty psalms and three scriptural passages, none of which were printed during James's lifetime. ${ }^{11}$ James Craigie has conjectured that this manuscript, written by the king and two scribes, was "a product of the late 1580s". ${ }^{12}$ The third and largest manuscript collection of James's verse, British Library MS Add. 24195, was compiled much later and comprises scribal copies "partially corrected by James". ${ }^{13}$ But it too includes poems composed during the 1580s and early 1590s: the most notable are twelve poems about love and women

\footnotetext{
${ }^{8}$ On the relationship between Essayes of a Prentise and James's assertion of kingship, see Sandra J. Bell, "Kingcraft and Poetry: James VI's Cultural Policy," in Reading Monarchs Writing: The Poetry of Henry VIII, Mary Stuart, Elizabeth I, and James VI/I, ed. Peter C. Herman (Tempe, Ariz., 2002), 155-78, and Jane Rickard, Authorship and Authority: The Writings of James VI and I (Manchester, 2007), 36-46.

${ }^{9}$ For a detailed description of MS Bodley 165, see The Poems of James VI of Scotland, ed. James Craigie, 2 vols. (Edinburgh, 1955-58), 1:1xxi-lxxvii. Two of the poems in this manuscript were printed in Essayes of a Prentise. These are Nos. 3 and 7 in Craigie's list of the manuscript's contents; in the printed collection they are titled "Ane Metaphoricall Invention Of A Tragedie Called Phoenix" and "A Paraphrasticall Translation Ovt Of The Poete Lvcane". Another two poems were printed in His Maiesties Poeticall Exercises. These are Nos. 1 and 2 in Craigie's list; the titles of the printed versions are "The Lepanto" and "The Fvries".

${ }^{10}$ Sebastiaan Verweij, The Literary Culture of Early Modern Scotland: Manuscript Production and Transmission, 1560-1625 (Oxford, 2016), 61, 59.

${ }^{11}$ For a full description of the manuscript, see Poems of James VI, ed. Craigie, 2:xxxiiixxxvii.

${ }^{12}$ Poems of James VI, ed. Craigie, 2:xvi.

${ }^{13}$ May, "Circulation in Manuscript," 207. The manuscript has been dated to between 1616 and 1618. For a full description, see Poems of James VI, ed. Craigie, 2:xxxvii-xlii.
} 
collected under the title "Amatoria," at least some of which were written around the time of the king's marriage in $1589 .^{14}$

It is clear, then, that by the mid-1590s James had amassed a substantial corpus of verse in manuscript, most of which had not appeared in print. Yet a question mark hangs over the extent to which James allowed others to read and copy his unprinted poems. In compiling his census of James's verse in manuscripts other than those described above, May found no copies of psalms or scriptural paraphrases from MS Royal 18.B.xvi and only one copy of a poem from MS Bodley 165. ${ }^{15}$ This poem, a complaint beginning "If mourning might amend my hard, unhappy case," appears along with twelve other poems or parts of poems by James in British Library MS Add. 22601, a manuscript of unknown origin compiled around the turn of the seventeenth century. ${ }^{16}$ There has been some debate about the authorship of these poems, which were later copied into MS Add. 24195 as part of the "Amatoria". However, May concluded that the poems were written by James and obtained by the unidentified compiler of MS Add. 22601 from the Scottish courtier Sir Thomas Erskine (later Earl of Kellie). ${ }^{17}$ Apart from these copies, May found only scattered evidence of the transmission of James's verse in manuscript before 1618. The dominant pattern, according to May, was one

\footnotetext{
${ }^{14}$ On the "Amatoria," see Sarah M. Dunnigan, "Discovering Desire in the Amatoria of James VI," in Royal Subjects: Essays on the Writings of James VI and I, ed. Daniel Fischlin and Mark Fortier (Detroit, Mich., 2002), 149-81, Morna R. Fleming, "The Amatoria of James VI: Loving by the Reulis," in Royal Subjects, ed. Fischlin and Fortier, 124-48, and Rickard, Authorship and Authority, 56-60.

${ }^{15}$ May, "Circulation in Manuscript," 218-22.

${ }^{16}$ For details of the manuscript and its contents, see Curtis Perry, "Royal Authorship and Problems of Manuscript Attribution in the Poems of King James VI and I," Notes and Queries 46 (1999): 243-46 at 244-45. The two versions of the poem beginning "If mourning might amend" in MS Bodley 165 and MS Add. 24195 are printed in parallel in Poems of James VI, ed. Craigie, 2:74-79.

${ }^{17}$ May, "Circulation in Manuscript," 215. The name " $\mathrm{S}$ Thomas Areskine of Gogar" is inscribed beneath the last of the thirteen "Amatoria" poems in MS Add. 22601. Perry interpreted this as an attribution and posited that the poems are the product of a "youthful collaboration" between James and Erskine. Perry, "Royal Authorship," 244. This interpretation was persuasively countered by Priscilla Bawcutt, who argued for James's sole authorship of the "Amatoria" in "The Authorship of James VI and I's Amatoria: The Manuscript Evidence,” English Manuscript Studies 1100-1700 15 (2009): 219-36.
} 
of "very limited circulation": individual poems by James were conveyed to "courtiers or court-connected recipients who seem to have circulated [them] no further". ${ }^{18}$ More recently, Verweij has sought to revise this picture of James as a poet whose unprinted verse reached a very restricted audience for the better part of his life. Verweij has drawn attention to James's habit of sending manuscript copies of sonnets to correspondents as a means of strengthening political and literary relationships. ${ }^{19}$ Verweij's research has also uncovered three manuscript copies of poems by James to add to those from before 1618 recorded by May. ${ }^{20}$ These copies demonstrate that at least a few of James's shorter poems travelled beyond the court and its immediate sphere of influence and reached a wider readership. However, Verweij found no hitherto unrecorded copies of poems from MS Bodley 165 or MS Royal 18.B.xvi. Though James emerged as a poet more widely read in manuscript than had been assumed, there remained a glaring lack of evidence of the circulation of much of the verse he wrote in the 1580 s and early 1590 s.

The Winchester copy of Essayes of a Prentise increases the number of poems from MS Bodley 165 and MS Royal 18.B.xvi known to have been in circulation before 1618 from one to four. Three poems by James were copied onto four endpapers that were almost certainly added to the book when it was first bound. ${ }^{21}$ Two are paraphrases of Psalm 148 and Ecclesiastes 12; there are authoritative versions of these poems in MS Royal 18.B.xvi. ${ }^{22}$ They are the first poems from the British Library manuscript to have been found elsewhere. The third poem is a misogynistic satire beginning "As falcons are by nature fair of flight"; there

\footnotetext{
${ }^{18}$ May, "Circulation in Manuscript," 214.

${ }^{19}$ Verweij, Literary Culture, 70-71.

${ }^{20}$ These are two copies of a poem beginning "Since thought is free think what thou will" in manuscripts held at the British Library and the National Records of Scotland, and a copy of a sonnet beginning "Not oriental Indus' crystal streams" in a manuscript held at Cambridge University Library. Verweij, Literary Culture, 65-69, 71.

${ }^{21}$ The original binding is now lost. In future references the endpapers are given the symbol $\chi$ and cited using their modern folio numbers.

${ }^{22}$ MS Royal 18.B.xvi, fols. 39r-41v (Psalm 148), 43r-v (Ecclesiastes 12), British Library.
} 
are versions of this poem in two of James's manuscript collections. MS Bodley 165 contains a holograph draft littered with revisions and inkblots. ${ }^{23}$ MS Add. 24195, on the other hand, contains a later copy made by James's son Charles in the "Amatoria" section of the manuscript. ${ }^{24}$ James is believed to have written "As falcons are by nature" and the paraphrases of Psalm 148 and Ecclesiastes 12 in the mid- to late 1580 s. $^{25}$ It is therefore possible that all three poems were added to the Winchester copy of Essayes of a Prentise before the publication of James's second printed collection of verse in 1591 . Very few readers are known to have obtained copies of more than one of James's unprinted poems before 1618. May uncovered only four: Sir Thomas Erskine and the unknown compiler of MS Add. 22601; “Ar. Harbert,” possibly Arnold Herbert of Monmouthshire, who attributed two epitaphs for Mary, Queen of Scots, to James in Emmanuel College, Cambridge, MS 89; and the compiler of Victoria and Albert Museum MS Dyce 44, which includes the same two epitaphs. ${ }^{26}$ The owner or owners of the Winchester copy of Essayes of a Prentise before 1618 can now be added to this list.

The manuscript poems at the back of the Winchester Essayes seem to have been copied by Scottish hands. The texts are markedly Scots in their orthography, and in this respect the versions of James's biblical paraphrases differ from the fair copies in MS Royal 18.B.xvi. These fair copies were made by a scribe who anglicized James's language and spelling, for example substituting "eche" for the more Scottish "ilk" and wh for Scots quh (in words such as "quhayles" and "quhom"). These changes are most apparent in the case of James's paraphrase of Psalm 148, as two copies of this poem are preserved in the British

\footnotetext{
${ }^{23}$ MS Bodley 165, fols. 43r-44v, Bodleian Library.

${ }^{24}$ MS Add. 24195, fols. 25r-27r, British Library. For the identification of the hand as Prince Charles's, see Poems of James VI, ed. Craigie, 2:209.

${ }^{25}$ Craigie conjectured that "As falcons are by nature" was written between 1584 and 1588 . Poems of James VI, ed. Craigie, 1:1xxiv.

${ }^{26}$ May, "Circulation in Manuscript," 209-11. The attribution of the epitaphs to James is doubtful.
} 
Library manuscript: a holograph copy and a scribal copy. ${ }^{27}$ As well as anglicising the text, the scribe altered five words in the poem as it came from James's pen. ${ }^{28}$ The Winchester copy of this poem incorporates four of the five seemingly authorized changes but reintroduces Scottish habits of spelling. ${ }^{29}$ The linguistic evidence places the Winchester Essayes firmly within a Scottish scribal environment.

Two copyists transcribed the poems onto the blank leaves at the back of the book. The first copied "As falcons are by nature" in a fairly cursive secretary hand consistent with a late sixteenth- or early seventeenth-century date (see Figure 1 ). ${ }^{30}$ This scribe took care to make an attractive copy: the manuscript is embellished with initials at the beginning of each stanza, looping pen flourishes in some of the upper and lower margins, and an ornamented double $f$ in the closing "ffinis". A title, "On Women," was added later in a hand that does not match Thistlethwayte's; the title of the following poem, "Psalm. 148.," is in the same hand. Apart from two minor variants, the text of the poem is substantively identical to the text that James drafted in MS Bodley 165. ${ }^{31}$ Verweij has described the contents of MS Bodley 165 as "the king's creased, stained, and much-thumbed working papers, mostly hidden from prying eyes". ${ }^{32}$ James may have kept these drafts to himself, but copies of some of the unprinted poems must have existed and been seen by others. In particular, James is thought to have shared poems that were later included in the "Amatoria" with members of an inner circle of courtiers and fellow poets, and occasionally with readers in the orbit of the court. Sarah

${ }^{27}$ MS Royal 18.B.xvi, fols. 39r-40v (holograph copy), 41r-v (scribal copy). The two versions are printed in parallel in Craigie's edition: Poems of James VI, ed. Craigie, 2:46-49. ${ }^{28}$ The scribal copy has "of" in place of "uith" in line 10; "nowyse" in place of "no uayes" in line 23; "dois" in place of "do" in line 26; and "and" in place of "or" in lines 43 and 44. Poems of James VI, ed. Craigie, 2:46-49.

${ }^{29}$ For a transcription of this text with a record of variant readings in the British Library manuscript, see Appendix.

${ }^{30}$ The intermittent use of italic forms of $f$ and $h$, as well as the more frequent use of secretary spurred $a$ and non-bodied $h$, points to a date around the turn of the seventeenth century.

${ }^{31}$ For a transcription of this text with a record of variant readings in MS Bodley 165 and MS Add. 24195, see Appendix.

${ }^{32}$ Verweij, Literary Culture, 61. 
Dunnigan has described the "Amatoria" as the product of an elite coterie held together by habits of "poetic exchange and "game". 33 As mentioned above, one of the two "Amatoria" poems in MS Bodley 165, "If mourning might amend," has been found in a manuscript miscellany associated with James's friend Erskine. "As falcons are by nature" is the second of the "Amatoria" poems in the Bodleian manuscript to be found in a copy outside of James's manuscript collections. This copy provides further evidence of James's willingness to share his poems. It is possible that, having composed "As falcons are by nature," a process recorded in MS Bodley 165, James shared the poem with a reader who either preserved it as an addition to an authorized printed collection of James's poetry or passed it to another reader who did the same. The Winchester copy of "As falcons are by nature" may derive from a simple chain of transmission initiated by James himself.

A second scribe copied James's biblical paraphrases in a formal humanist italic hand (see Figure 2). Like the first, this scribe added decorative touches, beginning many lines with flourished capitals and marking the end of the paraphrase of Psalm 148 with an ornamented "ffinis". But even though both poems were copied by the same scribe, it is likely that they were obtained through different channels. Firstly, the paraphrase of Ecclesiastes 12 is the only one of the three poems at the back of the Winchester Essayes with a title inscribed by its copyist (“Ecclesiastes xij”). James’s versions of Ecclesiastes 12 and Psalm 148 were both given titles by the scribe who copied them in MS Royal 18.B.xvi. ${ }^{34}$ The preservation of one title and the disappearance of the other in the Winchester Essayes suggest that the poems were copied by different scribes at some stage in their transmission. Secondly, the text of "Ecclesiastes xij" in the Winchester Essayes is less accurate than that of James's paraphrase of Psalm 148. The latter has just two readings that differ substantively from those of the fair

\footnotetext{
${ }^{33}$ Dunnigan, "Discovering Desire," 151. See also Rickard, Authorship and Authority, 56-57. ${ }^{34}$ These titles are "Psalme Cxlviij" and "Ecclesiastis Cap. xij.". Poems of James VI, ed. Craigie, 2:47, 50 .
} 
copy in MS Royal 18.B.xvi. By contrast, the former differs from the fair copy made by James's scribe in nine readings, which render the text less intelligible. ${ }^{35}$ These errors seem to be the result of misreading by a less careful copyist. Given that the italic scribe at work in the Winchester Essayes produced a highly accurate text of James's version of Psalm 148, it is more likely that the errors in "Ecclesiastes xij" were introduced by another scribe earlier in the poem's transmission. Verweij raised the possibility that other readers besides James's scribes had access to the British Library manuscript; however, he emphasized "that the papers remained in the king's possession, and that circulation will have been limited and carefully overseen". ${ }^{36}$ The Winchester Essayes demonstrates for the first time that poems from MS Royal 18.B.xvi were in circulation during James's lifetime, and it does not support Verweij's assumption. It seems that two of the poems from the British Library manuscript travelled beyond James's control and circulated separately among Scottish readers.

James is known to have shared copies of unprinted poems with privileged readers, and as Verweij has shown, some of these "small acts of targeted manuscript verse publication" precipitated wider circulation. ${ }^{37}$ This pattern of transmission may explain how the three poems by James came to be inscribed in the Winchester Essayes. The king could have given copies to individuals close to him, perhaps at different times, and those readers could in turn have shared the poems with relatives or friends, including the owner or owners of the Winchester Essayes. But unlike most of those known to have acquired unprinted poems by James, whoever owned this book when the manuscript additions were completed was able to gather together several unprinted poems by the king, probably from more than one source. Moreover, the owner or owners of the book chose to preserve these poems as a manuscript supplement to the first printed collection of the king's verse. For these reasons,

\footnotetext{
${ }^{35}$ For a transcription of this text with a record of variant readings in the British Library manuscript, see Appendix. There is no holograph copy of the poem in MS Royal 18.B.xvi.

${ }^{36}$ Verweij, Literary Culture, 64.

${ }^{37}$ Verweij, Literary Culture, 76.
} 
the copies in the Winchester Essayes are unlike any other known manuscripts of James's poetry. They provide insight into a scribal community in which James's printed verse could be read alongside sacred and secular poems from his personal manuscript collections.

II.

There is one other manuscript poem in the Winchester Essayes, which situates the book in a different scribal context—one of poetic responses to James's self-fashioning as a poet-king. Essayes of a Prentise opens with eight commendatory poems, which are separated from the main body of the collection by a blank leaf. ${ }^{38}$ In his survey of surviving copies of the Essayes, Verweij found that a copy in Lambeth Palace Library contains three additional commendatory poems in manuscript, occupying the blank space between the printed contributions and James's opening "Qvadrain Of Alexandrin Verse". ${ }^{39}$ These poems were probably composed by an English reader, who took the central allegorical element of James's poem "Phoenix" and turned it into an emblem of James himself, underscoring the king's remarkable rise from the ashes of his mother's reign. Verweij speculated that the author of these poems was invited to contribute adulatory verses to the Essayes, but "he (or she) somehow missed the print deadline". ${ }^{40}$ Like the Lambeth Palace Library copy, the Winchester copy of Essayes of a Prentise contains a manuscript addition to the printed sequence of commendatory poems: an unsigned sonnet, transcribed on the recto of the blank leaf before James's first verses. This unique poem shines a light on the response to James's poetic self-fashioning closer to home. The language and argument of the sonnet suggest that

\footnotetext{
${ }^{38}$ The blank leaf is A2. Like the other blank leaves in the book (O1, O3), it is missing from some extant copies. For a full description of the 1584 edition of Essayes of a Prentise, see Poems of James VI, ed. Craigie, 1:1xxvii-1xxix.

${ }^{39}$ Verweij, "“Booke, go thy wayes'," 121-25.

${ }^{40}$ Verweij, “"Booke, go thy wayes'," 129.
} 
it was written by a Scot who wished to add his or her voice to the chorus of praise for James, either from within the court or from outside it. In addition, the author of the sonnet may have been inspired not only by the commendatory poems in the Essayes but also by court poetry circulating in manuscript, including verse by James's "Master poët" Alexander Montgomerie. ${ }^{41}$

The sonnet is inscribed in a formal italic hand similar to that employed by the copyist of James's biblical paraphrases, but different enough to be identified as the work of another scribe (see Figure 3). ${ }^{42}$ The Winchester copy of the Essayes, like two-fifths of the copies surveyed by Verweij, has hand-ruled page borders, including on blank pages. ${ }^{43}$ The copyist of the sonnet took advantage of this, using the parallel rules at the top of the page as guidelines for the title and aligning all but the first line of the poem to the rule on the left of the page, leaving room in the margin for extravagantly flourished capitals. At the same time, the scribe did not take care to fit the text within the ruled borders, allowing it to run over on the right and at the bottom. I have found no record of other manuscript copies, nor any trace of the poem in print. It is transcribed below with minor emendations. ${ }^{44}$

THY race, quhilk you resemblis, come we reid Of Grecs \& Greice, quhilk greitest vves in gloires Quhilk did the sisters Citheriads breid,

${ }^{41}$ The quotation comes from the title of James's poem of friendly advice to Montgomerie, "An admonition to the Master poët": Poems of James VI, ed. Craigie, 2:120.

42 The sonnet is copied in a less angular and more right-leaning italic hand than the biblical paraphrases. This hand features a $h$ without a curving descender, loops on some ascenders (particularly those of the letter $d$ ), and double $v$ representing $w$ in a couple of places. ${ }^{43}$ Verweij, "'Booke, go thy wayes'," 116.

44 The scribal contraction of resemblis in line 1 and the abbreviation "qlk" in line 2 are expanded here. In addition, the digraph $t h$ is inserted in place of the letter $y$ where it represents the hard th sound. Grant Simpson explains that in Anglo-Saxon p, or thorn, represented the hard th sound, but the "form of this symbol had become debased by the late fourteenth century and it was now identical in appearance with the letter $y$. This convenient method of writing th, simply as a $y$, became very common". Simpson, Scottish Handwriting, 1150-1650: An Introduction to the Reading of Documents (Edinburgh, 1973), 42. 
Quha dois with laure thy Diademe decoire,

Quhairby thy weirds \& wirschip salbe moire,

Then thairs, that did ald Dardanie distroy:

Quha neuir haid sic honor heirtofoir

As of thair race is rissin sic a Roy.

As Pergame thai, sua sall you tak new troy,

And greiter wirschip sall obtene thairby,

And palme \& laure as vvirthiest, enioy.

Thy veirdis and werteu stryues as be inuy

The till aduance, $\&$ surlie to conserue:

That michtie Mars hes machit with Minerwe[.] ${ }^{45}$

This sonnet has the same interlocking rhyme scheme, later adopted in England by Spenser, as the five commendatory sonnets in the preliminary leaves of the Essayes. ${ }^{46}$ It also echoes the central argument of the first two commendatory sonnets in the book: that James has inherited the virtues of the ancients but is destined to surpass them as both a great ruler and a great writer. The first sonnet, by the court musician Thomas Hudson, compares James to the ancient Greeks and Romans, who are celebrated for their martial and literary achievements. According to Hudson, James has the same combination of strength and wisdom, bestowed on him by the gods: "he is one of Mars and Pallas race: / For both the Godds in him haue sett in frame / Their vertewes both". ${ }^{47}$ James's divine attributes are illustrated by the emblematic headpiece above the poem (see Figure 4). This woodcut depicts

\footnotetext{
${ }^{45}$ James VI/I, The Essayes Of A Prentise, In The Divine Art Of Poesie (Edinburgh, 1584), sig. A2r, Winchester College Fellows' Library.

${ }^{46}$ Essayes of a Prentise contains a total of twenty sonnets with the rhyme scheme $a b a b b c b c$ $c d c d$ ee. These were the first so-called 'Spenserian' sonnets to appear in print. On the history of the form in Scotland, see Katherine McClune, "The 'Spenserian Sonnet' in SixteeenthCentury Scotland," Notes and Queries, n.s., 56 (2009): 533-36.

${ }^{47}$ Thomas Hudson, "Sonnet," in James VI/I, Essayes Of A Prentise, sig. *2r.
} 
a crown transfixed by a sword and a laurel branch, framed by a banner with the motto "MARTE ET MINERVA". The next sonnet, by Thomas's brother and fellow musician Robert Hudson, declares that James has already surpassed both the great conquerors (Alexander and Augustus) and the great poets (Homer and Virgil) of ancient Greece and Rome. Consequently, the only person capable of adequately singing James's praises is James himself: "Coesars works, shall iustly Coesar crowne". ${ }^{48}$

The manuscript sonnet in the Winchester Essayes disregards ancient Rome, representing James as a descendant of the ancient Greeks. However, it agrees with the Hudsons' poems in emphasising James's capacity to outdo the ancients through his dual excellence as both ruler and poet: the octave suggests that it is the Muses' addition of "laure" to James's "Diademe" that sets him above his Greek ancestors. This imagery recalls the visual conjunction of the crown and the laurel branch in the headpiece to Thomas Hudson's sonnet. The motto displayed in the woodcut is also echoed in the final line of the manuscript sonnet: "That michtie Mars hes machit with Minerwe". If that is used here as a conjunction, meaning "since," the implication is that Mars and Minerva have united to magnify James's destiny and strengthen his character. ${ }^{49}$ The union of the gods in support of James is quite literally underlined by the scribe's joining of their initials. As in the ornamental woodcut, the names of Mars and Minerva are graphically yoked together. It seems, then, that the author of the manuscript sonnet took inspiration from the printed sonnets at the start of the book. Thomas Hudson's contribution, with its striking headpiece, appears to have made a particular impression, not only influencing the argument of the manuscript sonnet but also furnishing a mythological conceit for the closing line.

\footnotetext{
${ }^{48}$ Robert Hudson, "Sonnet," in James VI/I, Essayes Of A Prentise, sig. *2v.

${ }^{49}$ For this usage of that, see OED Online, s.v. "that, conj.," sense 4.c. https://oed.com/ (accessed March 2, 2021). I am grateful to one of the anonymous readers for suggesting this interpretation.
} 
But this is not the only possible interpretation. Poems in praise of James circulated in manuscript, and it is not inconceivable that the author of the sonnet in the Winchester Essayes was able to draw on a wider range of poetic models than those printed in James's collection. One poem that mirrors the themes and images of the Winchester text particularly closely is another manuscript sonnet proclaiming the young king's greatness, Alexander Montgomerie's 'In praise of his Majestie". Montgomerie's sonnet is reproduced here in full:

Support me sacred Sisters for to sing

His Praise vhilk passis the Antartik Pole

Quha fand the futsteppe of the fleing fole

And from Parnassus spyd the Pegase spring,

The hundreth saxt by lyne vnconqueist King,

Quhais knichtlie Curage kindling lyk a Cole

Maks Couarts quaik and hyde thame in a hole.

His brand all Brytan to obey sall bring.

Come troup of tuinis, about his Temple tuyn

3our laurell leivis with palmis perfytly plet

Wpon his heid Cæsarean to sett.

Immortalize ane nobler nor the Nyne,

A Martiall Monarch with Minerva's spreit,

That Prince vhilk sall the Prophesie compleit. ${ }^{50}$

Instead of the so-called 'Spenserian' rhyme scheme adopted by James and others, including the author of the Winchester sonnet, this poem follows the Italianate rhyme scheme

${ }^{50}$ Alexander Montgomerie, "In praise of his Majestie," in Poems, ed. David J. Parkinson, 2 vols. (Edinburgh, 2000), 1:104. 
developed by Sir Thomas Wyatt. ${ }^{51}$ Unlike the Winchester sonnet, moreover, Montgomerie's poem leavens its praise with playfulness, mixing mythological motifs and prophetic claims with burlesque images such as the humble coal that symbolizes the bright spark of James's valor. But underlying these differences is a common set of themes and mythological devices. Montgomerie and the author of the Winchester sonnet both imagine James crowned by the Muses: the former invites the "troup of tuinis" (siblings from a multiple birth) to bestow their honors on James, while the latter highlights the Muses' Greek ancestry by calling them "the sisters Citheriads", an unusual epithet derived from the name of a forest or mountain in their native Boeotia. ${ }^{52}$ The crown envisioned by Montgomerie is one of "laurell leivis with palmis perfytly plet [entwined]", symbolising James's union of eloquence and courage. The pairing of laurel and palm does not feature in any of the commendatory sonnets printed in the Essayes, but it is echoed in the Winchester sonnet, which imagines the symbolic "palme \& laure" as the king's ultimate prize. James's command of the arts of peace and war is underlined in the final couplet of both poems using the same mythological conceit. Like the Winchester sonnet, Montgomerie's poem closes by invoking the Roman gods of war and wisdom: James is characterized as “A Martiall Monarch with Minerva's spreit”. Finally, both poems call attention to James's illustrious ancestry as a Scottish king and forecast his future conquest of England. Montgomerie's sonnet predicts that James will unite "all Brytan" under his rule, while the Winchester sonnet looks forward to James's conquest of "new troy", or London, following in the footsteps of his ancient Greek ancestors.

\footnotetext{
${ }^{51}$ Twenty sonnets by Wyatt with the rhyme scheme $a b b a$ abba $c d d c$ ee were printed in Richard Tottel's Songes and Sonettes (1557). J. Christopher Warner, The Making and Marketing of Tottel's Miscellany, 1557: Songs and Sonnets in the Summer of the Martyrs' Fires (Farnham, 2013), 118.

${ }^{52}$ In his Anglo-Latin dictionary Thomas Cooper defined "Cythæron" as "A Forrest or wood in Bœotia, consecrated to the Muses". Cooper, Thesavrvs lingvae Romance et Britannicae (London, 1578), sig. 7H5v.
} 
Like most of Montgomerie's shorter poems, "In praise of his Majestie" has just one witness, Edinburgh University Library MS De.3.70, an anthology of Montgomerie's verse owned and probably compiled by a "Margarat Ker". ${ }^{53}$ Yet by the mid-1580s Montgomerie was the leading poet at James's court, and as Verweij has observed, he "must have relied on an extensive system of manuscript publication" of which few traces are left. ${ }^{54}$ Montgomerie's verse also reached an audience outside the court: none of the manuscripts compiled in Scotland before 1603 that contain poems by Montgomerie have courtly origins, a fact that "bears witness ... to exactly how porous the court was as a site for literary creation". 55 The circulation of Montgomerie's verse both at court and beyond leaves room for speculation that the author of the Winchester sonnet obtained a copy of "In praise of his Majestie" and drew on its rich variety of ideas and images in composing a new sonnet. Unlike Montgomerie, the author of the Winchester sonnet may not have been a practised poet. The sonnet lacks finesse: the octave is encumbered by pronouns ("quhilk" is used three times in the first four lines), and the sestet redeploys concepts and images that feature earlier in the poem ("greiter wirschip," the laurel, "Thy veirdis [destiny]"). The descriptive vigor of the commendatory sonnets printed in the Essayes is also absent: Thomas Hudson's poem has twice as many adjectives as the manuscript sonnet. Nonetheless, like other writers outside the court as well as within it, the author of the Winchester sonnet took the opportunity offered by the publication of the Essayes to celebrate James's poetic and political maturity. ${ }^{56}$

\footnotetext{
${ }^{53}$ Verweij, Literary Culture, 41.

${ }^{54}$ Verweij, Literary Culture, 38.

${ }^{55}$ Verweij, Literary Culture, 43. On the circulation and preservation of Montgomerie's poetry in manuscript, see also David J. Parkinson, "Alexander Montgomerie: Scottish Author," in Older Scots Literature, ed. Sally Mapstone (Edinburgh, 2005), 493-513. ${ }^{56}$ For examples of panegyric sonnets composed by a poet at some distance from the court, see Poems of John Stewart of Baldynneis, ed. Thomas Crockett, 2 vols. (Edinburgh, 1913), 2:159-62. On John Stewart's courtly poetry and the lack of evidence linking him to the court, see Verweij, Literary Culture, 47-50.
} 
Besides stylistic features, a number of other factors support the conclusion that the sonnet inscribed in the Winchester Essayes is a product of late sixteenth-century Scottish culture. The language is unmistakeably Scots: the rhyme "gloires”/“decoire,” for instance, couples two distinctively Scots forms. ${ }^{57}$ Furthermore, the poem was copied into a book that belonged to at least one Scottish reader with links to the king's scribal circles in the late 1580 s or 1590 s. But the most compelling factor of all is that the manuscript sonnet looks forward to the triumph of the Scots over their English neighbors. The poet represents the Scots as a people with a unique history, drawing on a national myth that developed in reaction against the myth of a united Britain propagated south of the border. The foundational text for this British national myth was Geoffrey of Monmouth's Historia Regum Britanniae, written in the twelfth century. According to this enormously influential account, the island of Britain was colonized by Brutus, a Trojan refugee who named the territory after himself and became its first ruler. On his death, Brutus's three sons “divided up the kingdom of Britain among them" and founded the nations of England, Scotland, and Wales. ${ }^{58}$ A supplement to the History foretold the eventual dissolution of these national boundaries and restoration of the kingdom of Britain: one of Merlin's prophecies predicted that "The island will be called by Brutus' name and the foreign term [Anglia] will disappear". ${ }^{59}$ The myth of a once and future kingdom of Britain was invoked by supporters of James in both Scotland and England to strengthen his claim to the English throne: if the two nations had a common British ancestry, James was not a foreigner but rather an Arthurian king poised to unite a divided

\footnotetext{
57 The Oxford English Dictionary records gloire as a "chiefly" Scots form of the noun glory and decoir as a Scots form of the verb decore. OED Online, s.v. "glory, $n$." and "decore, $v$." https://oed.com/ (accessed March 2, 2021).

${ }^{58}$ Geoffrey of Monmouth, The History of the Kings of Britain, ed. Michael D. Reeve, trans. Neil Wright (Woodbridge, 2007), 30.

${ }^{59}$ Geoffrey of Monmouth, History, 148.
} 
realm. ${ }^{60}$ However, this version of Scottish history had to compete with another narrativeone that asserted the historic independence of the Scottish nation. According to a Scottish historiographical tradition that became established in the fourteenth century, the Scots were not descended from the Trojans, as Geoffrey of Monmouth had claimed, but could instead trace their lineage back to another group of refugees, the Greek knight Gathelos, his Egyptian wife Scota, and their family. ${ }^{61}$ Hector Boece's popular Scotorum Historia, translated into the vernacular in the 1530s, asserted that the chivalrous Gathelos "namit his pepill Scottis eftir [his wife's] name", while their "vulgar laungage wes callit Gathelik". ${ }^{62}$ It is this tradition of historical writing that the Winchester sonnet alludes to in its opening lines: "Thy race, quhilk you resemblis, come we reid / Of Grecs \& Greice”. While addressing James, the poet gestures toward a community of readers for whom the story of Scotland's Graeco-Egyptian origins is part of a shared history.

The opening of the sonnet also echoes the beginning of one of Scotland's historical epics. The Wallace, a fifteenth-century verse narrative of the life of William Wallace and the battles he fought against the English, opens with an admonition to remember the nation's past:

Our antecessowris that we suld of reide

And hald in mynde, thar nobille worthi deid

We lat ourslide throw werray sleuthfulnes,

${ }^{60}$ See, for example, Sir John Harington, A Tract On The Succession To The Crown (A.D. 1602), ed. Clements R. Markham (London, 1880), 120-21, and John Leslie, A Treatise Tovvching The Right, Title, And Interest Of The Most excellent Princesse Marie, Queene of Scotland, And of the most noble king Iames, her Graces sonne, to the succession of the Croune of England (Rouen, 1584), fol. 70v.

${ }^{61}$ On the development of this origin myth in Scottish historical texts of the fourteenth and fifteenth centuries, see Emily Wingfield, The Trojan Legend in Medieval Scottish Literature (Cambridge, 2014), 22-51.

${ }^{62}$ Hector Boece, The hystory and croniklis of Scotland, trans. John Bellenden (Edinburgh, 1540?), sig. B1v. 
And castis ws euir till vthir besynes. ${ }^{63}$

The poem urges its audience not to forget the nation's historic enmity with the English, who "haff wrocht in-to thar mychty pryde / To hald Scotlande at wndyr [in a low state] euirmar". ${ }^{64}$ Like The Wallace, the Winchester sonnet reasserts Scotland's old enmity by looking back to the nation's ancestors: as descendants of the Greeks and the Trojans, the Scots and the English are hereditary enemies. The sonnet also finds in this legendary ancestry the seed of Scotland's future victory. James will emulate the triumph of his Greek ancestors: "As Pergame thai, sua sall you tak new troy". "Pergame" is a form of the name given in classical poetry to the citadel of Troy, glossed by Gavin Douglas in his sixteenth-century translation of The Aeneid as "Pergama, the Troiane wallys wyght [strong]". 65 "Pergame" had been destroyed long ago, but "new troy", the city that Brutus founded in his island kingdom, had grown into London. ${ }^{66}$ The sonnet anticipates the Scottish conquest of the English capital, putting an end not only to disputes about the English succession but also to centuries of struggle between the two nations.

Essayes of a Prentise was published at a pivotal moment for Anglo-Scottish relations. Though the exact date of publication is not known, the collection appeared within months of the opening of negotiations for an alliance between Scotland and England in August $1584 .{ }^{67}$ James's policy of amity with England met with opposition from his own lords: by early 1586, negotiations had stalled and a "broad coalition" of Protestants and Catholics was united

${ }^{63}$ Hary's Wallace (Vita Nobilissimi Defensoris Scotie Wilelmi Wallace Militis), ed. Matthew P. McDiarmid, 2 vols. (Edinburgh, 1968-69), 1:1.

${ }^{64}$ Hary's Wallace, ed. McDiarmid, 1:1.

${ }^{65}$ Gavin Douglas, Virgil's Aeneid Translated into Scottish Verse, ed. David F. C. Coldwell, 2 vols. (Edinburgh, 1957-64), 2:80 (bk. 2, ch. 5, line 79).

${ }^{66}$ According to Geoffrey of Monmouth, Brutus established "a city which he called New Troy" on the banks of the Thames: Geoffrey of Monmouth, History, 30.

${ }^{67}$ Verweij, "'Booke, go thy wayes'," 111. Ruth Grant, "The Making of the Anglo-Scottish Alliance of 1586," in Sixteenth-Century Scotland: Essays in Honour of Michael Lynch, ed. Julian Goodare and Alasdair A. MacDonald (Leiden, 2008), 211-36 at 211, 217. 
against the proposed alliance. ${ }^{68}$ The Winchester sonnet can be read as a veiled criticism of James's foreign policy. Echoing The Wallace, it implies that James is in danger of forgetting the dignity and independence of his "race"; it also insists that he will attain "greiter wirschip" through armed conquest. The poem clearly shows that despite his efforts to shape a new poetic culture James's control over the political uses of poetry did not extend beyond his own writings. In the treatise on Scottish poetry that he included in the Essayes, James instructed his fellow poets to avoid writing about political matters "except Metaphorically" and "very seindil [seldom]". ${ }^{69}$ Yet, as Sandra Bell has observed, James "could not close down the oppositional voices of poets and readers who employed and interpreted such 'metaphorical' verse". ${ }^{70}$ The Winchester sonnet is above all a poem of praise, which supports James's assertion of his dual authority as king and poet. At the same time, it could have been read, and may have been intended, as a challenge to James's official policy. Though the king may have wished to close off such interpretations, even the mode of courtly panegyric modelled by the Essayes contained the potential for political commentary.

III.

The Winchester copy of Essayes of a Prentise has one more set of manuscript additions, which bring the unsigned sonnet into dialogue with James's verse. Only one of the printed texts in this copy bears marks of reading: this is James's translation of "L'Vranie," a poem that first appeared in Du Bartas' collection La Muse Chrestiene in 1574 and was later

\footnotetext{
${ }^{68}$ Grant, "Anglo-Scottish Alliance," 221.

${ }^{69}$ James VI/I, "The Revlis And Cavtelis To Be Observit and eschewit in Scottis Poesie," in Essayes Of A Prentise, sigs. L1r-N1r at sigs. M2v-M3r.

${ }^{70}$ Bell, "Kingcraft and Poetry," 175.
} 
revised. ${ }^{71}$ A reader of the Winchester Essayes underlined one passage in James's translation and crossed out a word in another passage, writing a correction in the margin. Both passages contain references to the city of Troy. ${ }^{72}$ It is tempting to assume that the reader who marked these passages was also the author or transcriber of the manuscript sonnet, especially as the word supplied in the margin, "Pergame," is a name used in the sonnet. However, the correction and the sonnet do not appear to have been written by the same scribe: although both are in an italic hand, there are marked differences in some of the letter forms. ${ }^{73}$ It seems that the addition of a poem concerned with the history of Troy to the Winchester Essayes prompted another reader to look for references to the ancient city elsewhere in the collection. The markings on James's translation of 'L'Vranie' are sparse, and they may be evidence of highly selective reading. Yet it is clear that even a narrow focus on poetic references to Troy could yield insight into James's fallibility and creativity as a translator.

James's translation of Du Bartas' poem is printed in parallel with the French original in the Essayes. In his preface to the work James adopted the role of the humble "Prentise" that the title of his collection emphasized: he explained that he had placed the two versions side by side "to let appeare more plainly to the ... reader, wherin I haue erred, to the effect, that with lesse difficulty he may escape those snares wherin I haue fallen". ${ }^{74}$ The Winchester copy reveals a reader who did indeed discover an error in James's translation. In Du Bartas' poem, the poet is visited by Urania, the muse of astronomy, who urges him to devote himself

\footnotetext{
${ }^{71}$ On James's relationship with Du Bartas and his translation of "L'Vranie," see Peter Auger, Du Bartas' Legacy in England and Scotland (Oxford, 2019), 31-37.

72 There is only one other reference to Troy in the Essayes. The eighth of James's twelve sonnets addressed to the pagan gods recalls the death of "the Troyan trumpetour most raire", Misenus, in the sixth book of Virgil's Aeneid. James VI/I, "Sonnet. 8.", in Essayes Of A Prentise, sig. B3r.

${ }^{73}$ The closed, squat $P$, angular $r$, and $g$ resembling a slanted number 8 in the marginal correction differ from the letter forms in the sonnet.

${ }^{74}$ James VI/I, Essayes Of A Prentise, sig. C3v.
} 
to sacred subjects. To hone his craft, she advises him to study the literature of the pagan world, including the works once stored in its great libraries. James's translation reads:

How oft thou lykes reid ouer booke efter booke,

The bookes of Troy, and of that towne which tooke

Her name from Alexander Monark then[.] ${ }^{75}$

Troy is an incongruous partner to Alexandria in a passage about ancient libraries, and a glance at Du Bartas' text on the facing page reveals the source of the confusion. In the original Urania recommends "Les liures de Pergame": the books of Pergamon (or Pergamum), an ancient city whose library "was second only to [that of] Alexandria". ${ }^{76}$ James was tripped up by the ambiguity of "Pergame", which could refer to Troy, as it does in the manuscript sonnet. The reader of the Winchester Essayes, who had good reason to be attuned to the possible meanings of "Pergame", seems to have recognized James's mistake. The word "Troy" is lightly crossed out in this copy and the correction "Pergame" is supplied in the margin.

The same reader marked another passage earlier in James's translation. Here the poet recounts his youthful efforts to win fame and fortune by writing secular verse. The first three of the following four lines are roughly underlined in the Winchester Essayes:

I whyles essaide the Grece in Frenche to praise, Whyles in that toung I gaue a lusty glaise

\footnotetext{
${ }^{75}$ James VI/I, "The Vranie, Or Heavenly Mvse," in Essayes Of A Prentise, sigs. D1r-G1r at sigs. D4r, E1r. The French text on the facing pages reads: "Lis tant que tu voudras, volume apres volume, / Les liures de Pergame, \& de la grande cité, / Qui du nom d'Alexandre a son nom emprunté" ("Read as much as you want, volume after volume, / The books of Pergamon, and of the great city, / Which took its name from the name of Alexander"). Guillaume de Saluste Du Bartas, 'L'Vranie, Ov Mvse Celeste," in James VI/I, Essayes Of A Prentise, sigs. $\mathrm{C} 4 \mathrm{v}-\mathrm{F} 4 \mathrm{v}$ at sigs. D3v, D4v (my translation).

${ }^{76}$ Michael H. Harris, History of Libraries in the Western World, 4th ed. (Metuchen, N.J., 1995), 47.
} 
For to descryue the Troian Kings of olde,

And them that Thebes and Mycens crowns did holde. ${ }^{77}$

In his manual of Scots poetry, "Revlis And Cavtelis [cautions]," printed in the Essayes, James warned translators not to "essay [...] zour awin ingyne of Inuentioun," as "ze are bound, as to a staik, to follow that buikis phrasis, quhilk ze translate". ${ }^{78}$ But James did not practise what he preached. In the lines quoted above, he altered the sense of the original to suppress politically unpalatable meanings. In Du Bartas' version of the lines, the poet recalls that he once devoted his energies to drama: he translated Greek drama into French and wrote original plays depicting the bloody rule of the tyrants of Troy, Thebes, and Mycenae. ${ }^{79}$ James's translation strips the passage of its references to the stage: the poet reveals only that he ventured "to praise" and "to descryue" the ancients. The translation also removes all mention of tyranny: in James's version, the rulers of Troy, Thebes, and Mycenae are "Kings", not tyrants. Stories of bad kings had been used by Scottish writers to argue for a constitutional theory of monarchy that justified the deposition of vicious rulers. ${ }^{80}$ James resisted the spread of these ideas from the very beginning of his personal rule: in 1584 , the year in which the Essayes was published, an act of parliament proscribed George Buchanan's

77 James VI/I, "The Vranie," sig. D1r. The meaning of "glaise" in this context is uncertain. The Dictionary of the Scots Language records that the word was used before 1700 to mean "A touch of fire, a burn"; however, James's usage has a separate entry without a definition. Dictionary of the Scots Language, s.v. "Glaise $n .1$," https://www.dsl.ac.uk/entry/dost/glaise_n_1 and "Glaise $n .{ }^{2}$, ", https://dsl.ac.uk/entry/dost/glaise_n_2 (accessed March 2, 2021).

${ }^{78}$ James VI/I, "Revlis And Cavtelis," M2v. On James's translation of "L'Vranie" and his discouragement of "Inuentioun" in political poetry, see Auger, Du Bartas' Legacy, 34-36. ${ }^{79}$ The French text printed alongside James's translation reads: "Tantost i'entreprenoy d'orner la Grecque Scene / D'vn vestement Francois. Tantost dvn vers plus haut, / Hardi, i'ensanglantoy le François eschafaut / Des Tyrans d'Ilion, de Thebes, de Mycene" ("Sometimes I undertook to deck out the Greek stage / In French garb. Sometimes, in a higher strain, / Bold, I bloodied the French scaffold / With the tyrants of Ilion, of Thebes, of Mycenae"). Du Bartas, "L'Vranie," sig. C4v (my translation).

${ }^{80}$ Jenny Wormald, "James VI and I, Basilikon Doron and The Trew Law of Free Monarchies: The Scottish Context and the English Translation," in The Mental World of the Jacobean Court, ed. Linda Levy Peck (Cambridge, 1991), 36-54 at 40-42. 
defence of constitutional monarchy, De Iure Regni apud Scotos (1579). ${ }^{81}$ James's replacement of tyrants with kings in his translation of " $L$ 'Vranie" provides further testimony of his desire to assert the authority of kings in the face of examples of royal tyranny. Meanwhile, James's reframing of the ancient rulers as historical figures rather than theatrical characters is suggestive of an unease about the theatricality of kingship that would find expression in later writings. In Basilikon Doron (1599), the manual of kingship that he dedicated to Prince Henry, James observed that " a King is as one set on a skaffold, whose smallest actions \& gestures al the people gazingly do behold". ${ }^{82}$ As Verweij has pointed out, the primary meaning of "skaffold" in this context is "platform" or "stage", but the word also "carries darker connotations": exposure to public scrutiny could be not just uncomfortable but dangerous for a king. ${ }^{83}$ The violence hinted at in Basilikon Doron is enacted in Du Bartas' poem, as the poet recalls staining the French stage (literally, the "eschafaut" or scaffold) with the blood of tyranny. James erased this image of the staging of power from his translation of the poem, but the idea of a king "set on a skaffold" was to return in his later work.

Did the reader who marked this passage in the Winchester Essayes recognize that James had altered Du Bartas' meaning? The untidy underlining gives nothing away. Taken together, however, the markings in this copy, sparing as they are, reveal a reader who viewed James's "Vranie" through the lens of references to Troy—a very minor thematic component of a poem calling for the revival of Christian poetry. This reader may not have been the author of the sonnet lauding James as the future conqueror of "new troy". Yet the story of Troy seems to have played a major role in shaping their perception of James both as a king and as a poet.

\footnotetext{
${ }^{81}$ Bell, "Kingcraft and Poetry," 161-62; Wormald, "James VI and I," 44.

${ }^{82}$ James VI/I, Basilikon Doron (Edinburgh, 1599), sig. R1r.

${ }^{83}$ Verweij, Literary Culture, 54.
} 
IV.

The Winchester copy of Essayes of a Prentise is a unique specimen of late sixteenth-century Scottish courtly literature. It is the only copy of James's first publication known to contain additional poems by the king in manuscript, and it is the only witness to the sonnet beginning “Thy race, quhilk you resemblis, come we reid," an example of Jacobean courtly panegyric. Yet there is no evidence that the Winchester Essayes was ever in the hands of a member of the Jacobean court. In Verweij's terms, it is a book that contains an extraordinary group of courtly poems in manuscript, but its additions cannot positively be described as "of the court": it is not known whether they were copied by or on behalf of members of the royal household or the court's other constituent groups. ${ }^{84}$

Nevertheless, the Winchester Essayes enriches our understanding of both the circulation of poems by the king and the politics of courtly poetry. Verweij demonstrated that before 1618 James shared several of his poems in manuscript with courtiers and other individuals, some of whom circulated them further. However, all of the poems Verweij discussed are shorter works that seem to have circulated as individual examples of the king's verse. The Winchester Essayes allows us to see beyond this pattern: it shows that a wider variety of James's poems were in circulation before 1618, including a number of his biblical paraphrases, and that some readers were able to form collections of the king's unprinted verse. The Winchester copy also shines a spotlight on the influence of the succession question on the reception of the Essayes in Scotland. Recent scholarship on the reception of James's early poetry has drawn attention to the influence of his printed works on English

\footnotetext{
${ }^{84}$ Verweij, Literary Culture, 26-27.
} 
literary culture and English attitudes toward the Stuart claim to the throne. ${ }^{85}$ The manuscript sonnet in the Winchester copy is a rare illustration of how the succession question shaped the response to the Essayes at home rather than abroad. Thistlethwayte may have valued his copy of the Essayes as a rare document of the early years of a "King of England," but there is much that we can learn about the literary culture of late sixteenth-century Scotland from this remarkable book.

${ }^{85}$ Verweij, "'Booke, go thy wayes"”; see also Richard A. McCabe, "The Poetics of Succession, 1587-1605: The Stuart Claim," in Doubtful and Dangerous: The Question of Succession in Late Elizabethan England, ed. Susan Doran and Paulina Kewes (Manchester, 2014), 192-211 at 199-205, and Deirdre Serjeantson, "English Bards and Scotch Poetics: Scotland's Literary Influence and Sixteenth-Century English Religious Verse," in Literature and the Scottish Reformation, ed. Crawford Gribben and David George Mullan (Farnham, 2009), 161-89. 
On Women -

(2) farcomio as byo natros fario of funfe

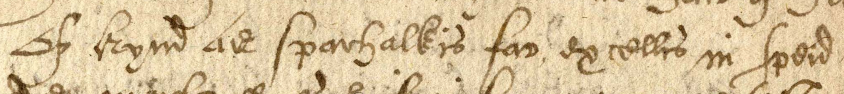

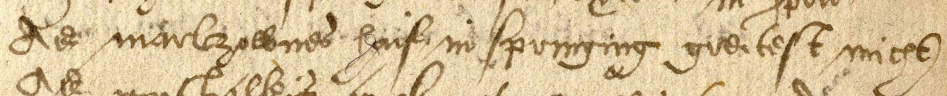

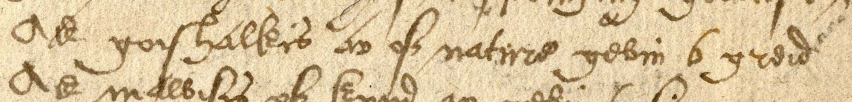

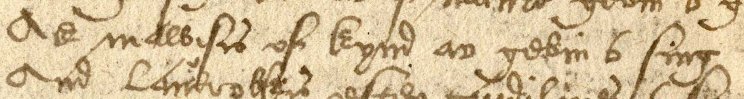

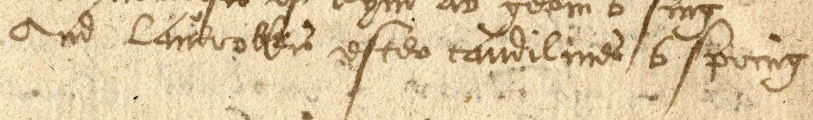

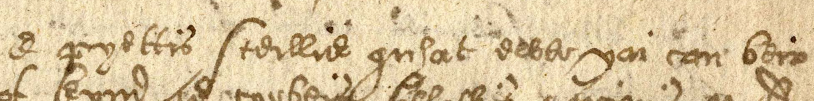

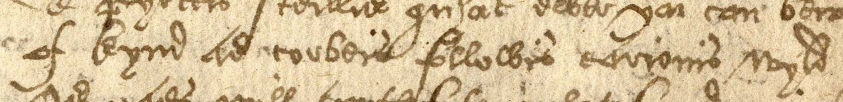

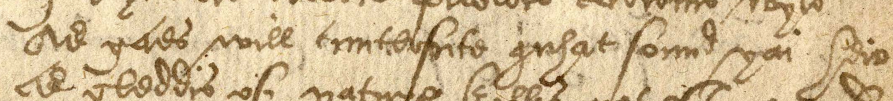

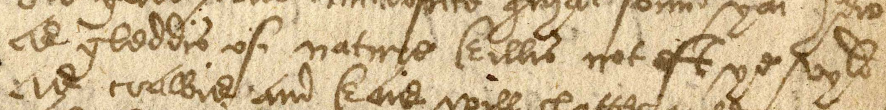

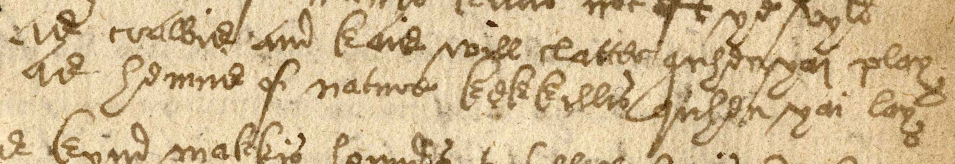

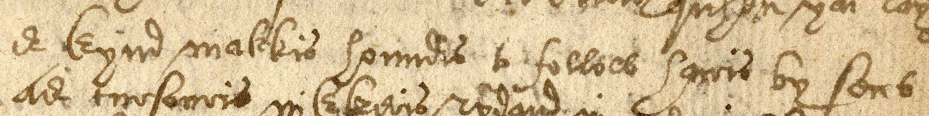

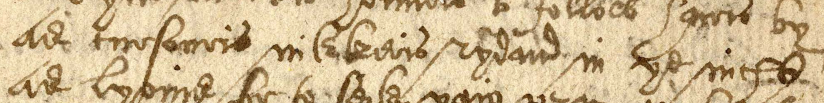

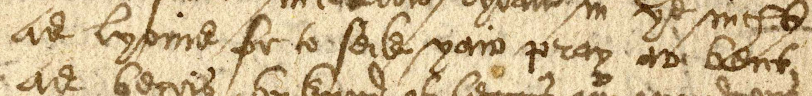

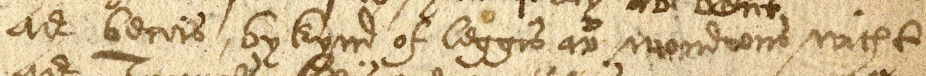

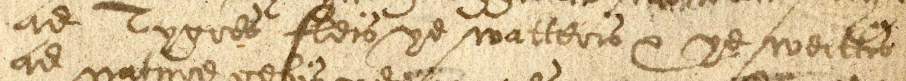

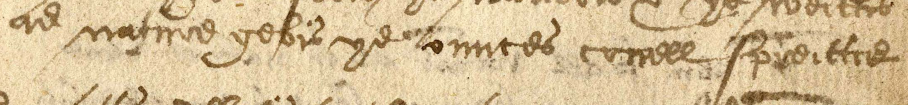

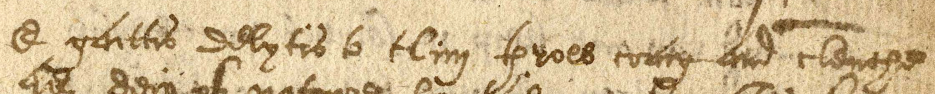

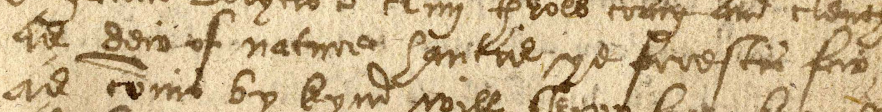

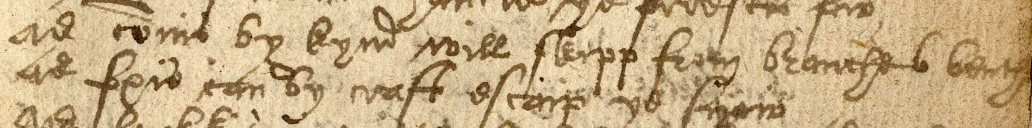

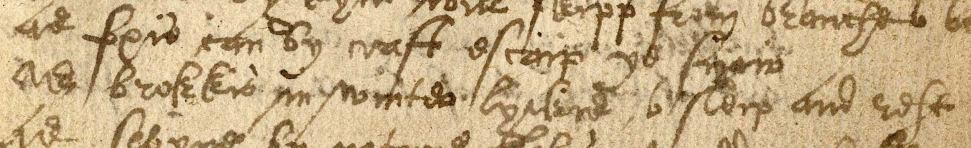

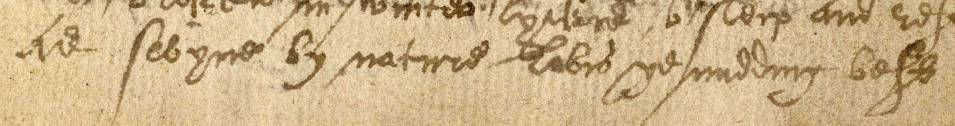


A.

$x$

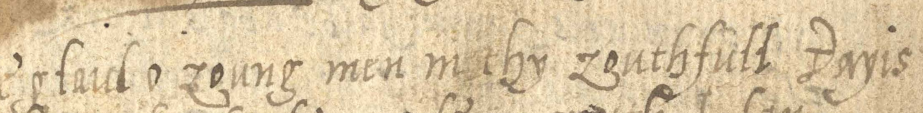

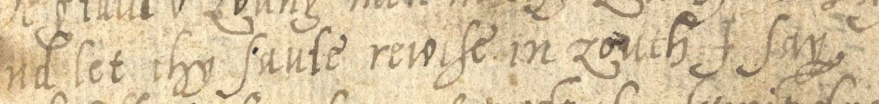
And follow furt ft yat insst tor Jureit dons prise?

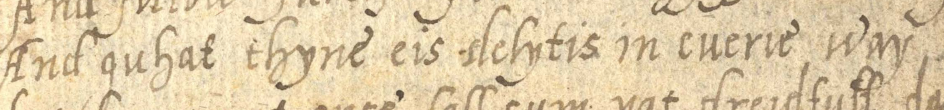
bot fenau yat once' fall'cum yat frendfuft dat. guben for thois deudis yod faff exame ye gö

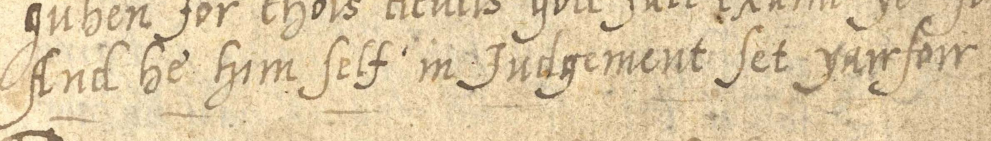

Remoue becue all rantor from igy brawe' contemm ifr fefefe, bnvorfore eurll at all for zoufb lfuill as ifgr fhenc is bot vane. yancom on thy erentur tbmk you fall frit anfun $x e$ tome is not anfen you arc ax Q Gon mitfor ziris my yeafur is nesm. A nol oufilf ye' fone and lingt is not of enrite and oufirlye monne and farris ar fofgnin brichto

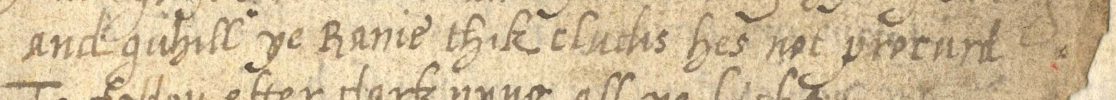
Jo Joton efter darkinny all ye liffo 2. ufat by nai $\sqrt{a l b c}$ boued vat ar of misft

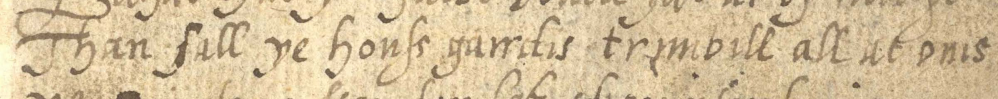
Jo arinderan Jogy for lak of counter bonis 

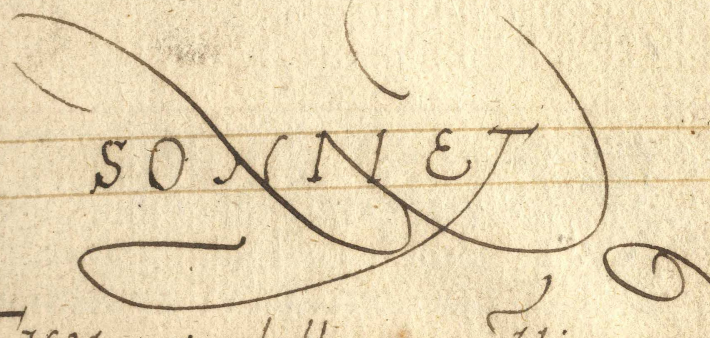

I H Y Yrace' qubullz you veseblis come ssereid.

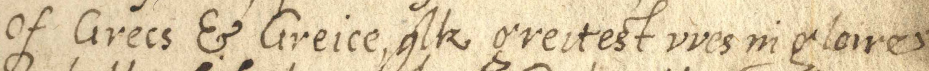
Qublk did the sisters Githerifs breid 2 uha dois with faure thy Diddeme decoin, 2uhariby thy Werids ov virstrip falbe mome $\longrightarrow$ Thenyairs, that did ald Dardanie disfroy: Quha neuir band fic bonor Gentofom Is of yari race is rissm fic a Rov. Is Pergame yai sua falt you tak nरि troy. And coveiter toms blup sall ob tene thamby,

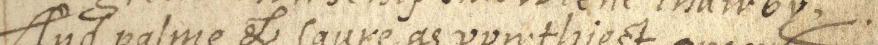
In palime as anroy. Ihy verdis and werten stryues as be miny The till aduance, Efurlie to conseruc: 5 $\longrightarrow$ That mish tie Mars hes makbut with 72 merrese 


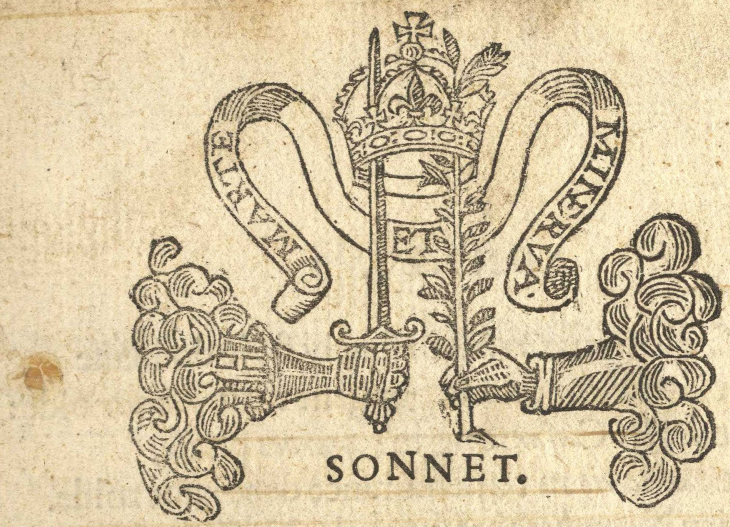

F Martiall deeds, and practife of the pen

Haue wonne to auncient $G$ rece a worthie fame:

If Battels bold, and Bookes of learned men

Haue magnified the mightie Romain name:

Then place this $\mathrm{Prince}$, who well deferues the fame:

Since he is one of Mars and Pallas race:

For both the Godds in him haue fett in frame Their vertewes both, which both, he doth embrace.

O Macedon, adornde with heanenly grace,

ORomain ftout,decorde with learned fkill,

The Monarks all to thee fhall quite their place:

Thy endles fame fhall all the world fulfill.

And after thee, none worthier fhalbe feene,

To fway the Svvord,and gaine the Laurell greene.

$$
\begin{aligned}
& \text { T. H. } \\
& \text { *ैij }^{*} \text {. }
\end{aligned}
$$




\section{Image Captions}

Figure 1: James VI/I, "As falconis ar bye nature fair of flicht," in Essayes of a Prentise, fol. $\chi 1 \mathrm{r}$, Winchester College Fellows' Library. By kind permission of the Warden and Scholars of Winchester College.

Figure 2: James VI/I, "Ecclesiastes xij," in Essayes of a Prentise, fol. $\chi 4 \mathrm{r}$, Winchester College Fellows' Library. By kind permission of the Warden and Scholars of Winchester College.

Figure 3: Manuscript sonnet, in James VI/I, Essayes of a Prentise, sig. A2r, Winchester College Fellows' Library. By kind permission of the Warden and Scholars of Winchester College.

Figure 4: Thomas Hudson's sonnet with emblematic headpiece, in James VI/I, Essayes of a Prentise, sig. *2r, Winchester College Fellows’ Library. By kind permission of the Warden and Scholars of Winchester College. 


\section{Appendix}

\section{Transcriptions of Manuscript Poems by James VI/I in the Winchester Copy of Essayes of a Prentise}

Note on conventions: The letter $y$, where it represents the same sound as Anglo-Saxon $p$ (thorn), has been transcribed as $t h$, and the letter $z$, where it represents the same sound as Anglo-Saxon 3 (yogh), has been transcribed as $y .{ }^{1}$ Superscript letters have been lowered. Contractions have been expanded and omitted letters supplied in italics. Letters omitted without a mark of contraction have been supplied in square brackets. Text crossed out in the manuscript is given in angle brackets.

Substantive variants found in other manuscript copies of the poems are given to the right of the text. The following abbreviations are used to denote their sources:
A British Library, MS. Add. 24195
B Bodleian Library, MS Bodley 165
Rh British Library, MS Royal 18 B.xvi, holograph copy
Rs British Library, MS Royal 18 B.xvi, scribal copy

Fol. $\chi 1 r$

$$
\text { On Women }-{ }^{2}
$$

As falconis ar bye nature fair of flicht

Of kynd as sparhalkis far excellis in speid

As marlyownes haif in springing greitest micht

As goishalkis ar of nature gevin to greid

As mawisis of kynd ar gevin to sing

And lauerolkis efter candilmes to spring

As pyettis steillis quhat ewer thai can beir of kynd as corbeis followis carionis wyld As gaes will cunterfute quhat sound thai heir as gleddis of nature killis not oft the vyld as crawis and kais will clatter quhen thai play as hennis of nature kekkillis quhen thai lay

As kynd makkis houndis to follow hairis by sent

\footnotetext{
${ }^{1}$ Grant Simpson explains that the Anglo-Saxon symbol 3 came to be "used in Scots vernacular texts as an equivalent for consonantal $y$ " and by the later middle ages it had become "indistinguishable in written form from $z$ ". Simpson, Scottish Handwriting, 11501650: An Introduction to the Reading of Documents (Edinburgh, 1973), 42. On the letter $y$ and the Anglo-Saxon symbol p, see p. 13, note 44.

${ }^{2}$ This title and the title of the next poem are not in the same hand as the poems themselves. For further details, see p. 9.
} 
as cursouris nikkeris rydand in the nicht as lyonis for to seik thair pray ar bent as beiris, by kynd of leggis ar wondrous wicht as Tygres fleis the watteris $\&$ the weittis as nature gevis the ounces cruell spreittis

As gaittis delytis to clim throw craig and cleuche as deir of nature hantis the forrestis fair,

as connis by kynd will skipp from branche to beuch as foxis can by craft escaip the snair as brokkis in winter lyckis, to sleip and rest as swyne by nature lovis the midding best

Fol. $\chi 1 v$

As scooles of hering fleis the quhale for feir as greit auld pykis will eit the young \& small as remora will stopp, ane schip to steir as kynd makkis sea horss to be cruell all as kynd makkis creuissis to swim a bak as troutes of nature fischear baitis will tak

As Marmaides haitis all men by naturis will as dallfinis loves all bairnes in wondrous soirt as by the contrar Crocodiles thame kill as Mereswynes loves of nature for to spoirt of kynd as salmound in fresche riveris spawnes as selchis haif milk \& young onis laiking rawnes

In schorit as fowles by kynd in air do flie and as the beastis by nature go on ground and as the fisches swimmes in frothie sie and as all leving thingis ar euer bound

To follow nature rewling tham alway quhose will they must obey but let or stay

Ewin so all wemen ar of nature vane and can not keip in secreit unreweylit and quhair as once they do consave disdane thay ar unabill to be reconceillit fulfillit with talk \& clatteris but respect and oftintymes of small or non effect

Fol. $\chi 2 r$

Ambitious ar without regard or schame but anye measure gevin to greid of geir ar] all $\mathrm{A} \mathrm{B}$ desyring euer for to win a name with flattering all that will tham not forbeir Sum craft thai haif yit foolische ar indeid

they must obey] B; obeye they must A

in] no A B 
with leing quhyles esteming best to speid

Excuse

Expone me richt ye dames of worthie fame since for yor honors I employit my cair For wemen bad, heirbye ar less to blame for that thai follow nature euerie quhair And ye most worthie prais quhose reasoun dantis That nature, q[uhi]lk into yor sex so hantis

ffinis

Fol. $\chi 2 v$

Psalm. 148.

Sing laude vnto the lord Heauenis induellaris, I say

To do the same accord In places hie, and stay

And so alwayise

ye angelis all

Greit hoistis, and tall Iehoue prayise

Prayse him, both sunne, and moone.

And starres, of schyning, licht

The sam of you be done

ye heauenis, of heauenis most bricht

Set furth his fame

ye watteris eauen

above this heauen

And praise his name

All ye quho by his will, and word, created bene:

Praise great Iehoua still:

Quho dois yow ay contene

In stablist rest

Quhose iust decree

can nouayis be

By ocht transgrest

Fol. $\chi^{3 r}$

Praise him eache leauing beast

That on the earthe dois go:
Excuse] B; Exposition A

60

of] Rs; uith Rh

10

nouayis] Rh; nowyse Rs

dois] Rs; do Rh 
Thou deaph ${ }^{3}$ with most, and least of fische, and whailis, also,

Thou glanceing loue,

Hayll roundly rolde

Snow, whyte, and colde

His praise furth shoue.

Ye exallationis wak

with stormy, wyndis, and shill

whome he dothe euer mak

His worde for to fulfill

ye cidres great

Hudge hillis, and knouis

frute treis that growis

praise godis hie seat

Ye beastis and cattell tame,

eache foule, and creping thing

eache people, and prince of name:

eache earthly Iudge, and king

ye uirginis eik

ye babis and olde

with young men bolde

His praise furth speik

Fol. $\chi^{3 v}$

ffor that his name allone

Doth heauen and earth adorne:

He is that onely one

Exaltis his peoples horne

thair praise I mene

Of israell

Quhome he luifis well

praise god diuine

ffinis

Fol. $\chi 4 r$

Ecclesiastes xij

Be glaid o young men in thy youthfull dayis and let thy saule reioise in youth I say

And follow furtht that most thy spreit dois praise

And quhat thyne eis delytis in euerie way

bot knau that once sall cum that dreidfull day

quhen for thois deidis god sall exame the soir

\footnotetext{
${ }^{3}$ This may be a variant or incorrect spelling of depth.
}

deaph] deepe $\mathrm{Rh}$; deape

Rs

40

and] Rs; or Rh

and] Rs; or Rh

men] man Rs

that] what Rs 
And he him self in Iudgement set thairfoir

Remoue beleue all rancor from thy brane contemm thy flesche vnworking euill at all for youth alsueill as chylheid is bot vane

contemm] Contene Rs 10

fail] fall Rs

thairfoir on thy creatur think you sall

quhill in thy lothsum dayis, you $<$ sall say $>$ dois not fail

And quhill the tyme is not quhen yow sall say

Nou in thir yeiris my pleasur is away

And quhill the sonne and licht is not obscurde and quhill the monne and starris ar schyning bricht and quhill the Ranie thik cludis hes not procurd To follou efter darknyng all the licht Quhat tym thai salbe boued that ar of micht Than sall the houss garrdis trimbill all at onis the grinderis stay for lak of counter bonis

Fol. $\chi 4 v$

Thay salbe dimed that throt[h] the wyndois keik the vtter durris thai salbe schot als sone als sone] assone Rs the grinderis sonne salbe abassid eik He sall auaik than at the lauerokis tone His hoill delyte in singing salbe done And thai salbe for hie thingis soir affrayit And feir sall mak tham in the way dismaid

Then sall the almond tree be floreshit fair the gershopper sall bayt[h] be hauie and greit 30 he sall of $1^{4}$ lust and pleasur haif no cair for man drauis neir to his eternall seit And doill in streit luikis for him air and lait quhill tyme the siluer clud yit will not rax and goldin circles nayer brekis nor crakis

clud] corde Rs

And quhill the picher brekis not at the well Nor quhill the cisterne than it cumis at last that dust returnis in earth and in it sell the spreit returnis to god quhome for it past from ony trubill fred or warldlie blast All varietie all vanitie most vane all thir ar vanitie: I say agane

the] at Rs

for] fro Rs 40

varietie] vanitie Rs

finis

\footnotetext{
${ }^{4}$ This letter was traced twice by the scribe and then abandoned.
} 